\title{
Determination of limits for acoustical pollution from main roads at the stage of urban area zoning
}

\author{
Oleksiy Priymachenko ${ }^{1}$, Tetiana Shilova ${ }^{2}$ \\ Kyiv National University of Construction and Architecture \\ 31, Povitroflotskyi Avenue, Kyiv, Ukraine, 03037 \\ 1 priymachenko a@ukr.net, orcid.org/0000-0001-5125-8472 \\ 2tatyanashilova1957@gmail.com, orcid.org/0000-0002-8214-6964
}

The manuscript was received on 26.07.2017 and was accepted after revision for publication on 05.10.2017

DOI: $10.26884 / 1707.1802$

\begin{abstract}
The intensive automobilization of cities involves some problems relating to traffic arrangement, and as a result, requires to extend the transportation corridors of main trunk road networks, increase traffic capacity, and develop models of transportation flows in the conditions of existing urban development. In such conditions, environmental pressures on urban areas increase. The impact of technogenic factors on the areas also increases, and as a result, the concentration of environmental pressures enhances. The desire to increase the traffic capacity and city building density can induce ecological instability of some urban areas. At the present time, there are normative documents that regulate the conditions for development and planning of urban areas.

The functionality of urban areas and environmental pressures on the areas and their limits must be clearly determined at the stages of developing the general plans and detailed plans of the urban area development.

In the conditions of decentralization and formation of territorial communities, which are entitled to independently deal with their financial problems and form social living environment, it is required to use comprehensive professional methods for designing strategic programs for the development of cities and settlements.

At the present time, city planning specialists are capable of taking into account various factors relevant to the development and planning of urban areas with consideration for future environmental pressures and their limits. Due to this, it will be possible to save financial costs when carrying out actions required for decreasing the technogenic
\end{abstract}

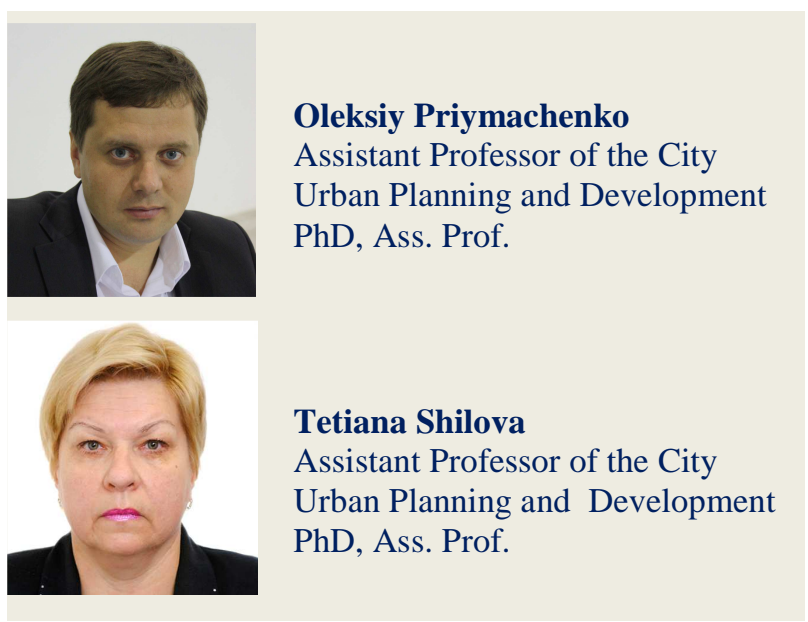

impact on the ecology and living environment, and planning the perspectives of regional development.

For this reason, the analysis of environmental pressures from the city main roads network is relevant for any city.

This paper contains the calculated data on the results of analysis of the city main roads characterized by different planning concepts.

These data are required for determining the corresponding planning actions.

Keywords: noise propagation paths, limiting acoustic discomfort characteristics, isodecibels.

\section{INTRODUCTION}

Acoustic pollution of urban areas is one of the negative results of the intensive automobilization of the country cities. The determination of levels of noise generated by various 
noise sources, as well as the estimation of noise propagation within the urban area is characterized by specific features and depends on the noise source characteristics and on the city planning stage at which the noise propagation is estimated. With consideration for this, at the detailed planning stage, an effective method was developed for drawing up noise charts for stationary and mobile noise sources. This method allows constant noise level lines (isodecibels) clearly to be drawn, and accordingly, the noise level in every specific urban area to be determined. For this purpose, it is required to have cartographic documents for the city planning area, at a scale of 1:500 through 1:2000, data on the road cross sections and road characteristics, and data on the parameters of transportation flows. But at the stages of technical and economic assessment, development of diagrams and projects according to the general city planning scheme, and preparation of cartographic documents at a scale of 1:10000 through 1:25000, or even 1:50000, there are no need and possibility to draw up the detailed charts characterizing the noise pollution in the areas studied. At these project stages, the estimation of acoustic pollution consists only in determining the predicted noise levels from various noise sources and drawing up noise diagrams. In this case, it is possible to compare different main roads depending on noise levels and distinguish the noisiest streets, but it is impossible to estimate the degree of noise propagation within the urban area.

\section{STATEMENT OF THE PROBLEM}

The purpose of this study is to determine the limits of acoustic impact of the city main roads when specifying the functionality of the urban areas at the stage of zoning the urban area and designing the detailed urban area plan. The development of a model for environmental pressures, with consideration for their impact, and the prediction of extension of the environmental pressures on the certain planning area is one of the purposes of activity in city planning.

\section{ANALYSIS OF THE LATEST RESEARCH AND PUBLICATIONS}

The results of analysis of scientific papers and effective normative documents relating to city planning demonstrate the actuality of this study issue, as the intensive automobilization of cities more and more promote the study of factors which have an effect on transportation flows simulation and on environmental pressures on the urban area. The city transport and the ecological state of the city environment are subjects of studies by such well-known specialists as Solukha B.V. [3], Fuks H.B. [3], Furmanenko O.S. [4], Shilova T.O. [5], Ustynova I.I. [6], Solukha I.B. [7], Diomin M.M., Reitsyn Ye.O., and others. The stable integrated approach in performing scientific studies will promote the introduction of new practical methods in the planning and arrangement of urban areas at the corresponding planning stage.

\section{LIMITS FOR ACOUSTICAL POLLUTION FROM MAIN ROADS AT THE STAGE OF URBAN AREA ZONING}

For the predictive estimation of noise pollution of urban areas from line noise pollution sources, a method was developed for analyzing propagation of noise from the city main roads inward the urban areas located near the streets [23, 24]. Specifically, at the stage of the urban area zoning, when different functional zones in the urban area are to be identified, there is a possibility to take into account the normative allowable noise levels and the characteristic features of the corresponding urban areas [25].

In this case, the following unbuilt and builtup urban areas with various allowable noise levels are defined:

- built-up areas with buildings for therapeutic, recreation, and fitness purposes: $50 \mathrm{~dB}(\mathrm{~A})$;

- unbuilt areas and built-up areas with lowrise, high-rise, and mixed buildings: $55 \mathrm{~dB}(\mathrm{~A})$; 
- areas with long-completed buildings, which are subjected to reconstruction, and areas of industrial enterprises and estates: 60 $\mathrm{dB}(\mathrm{A})$.

When performing acoustical analysis in such a case, it is recommended to determine noise pollution paths, that is, the areas located near line noise pollution sources, such as automobile roads and railways, with noise levels arranged between the isodecibels corresponding to the normative noise levels. It is accomplished by plotting limiting acoustic discom- fort characteristics, which separate noisepolluted areas from areas with acoustic comfort conditions, that is, from the areas where noise levels are less then the noise levels specified in the sanitary standards [23, 24].

It is appropriate to determine the width of noise propagation paths according to the method described in [26], using a noise recorder developed in the Dnipropetrovsk Civil Engineering Institute [27].
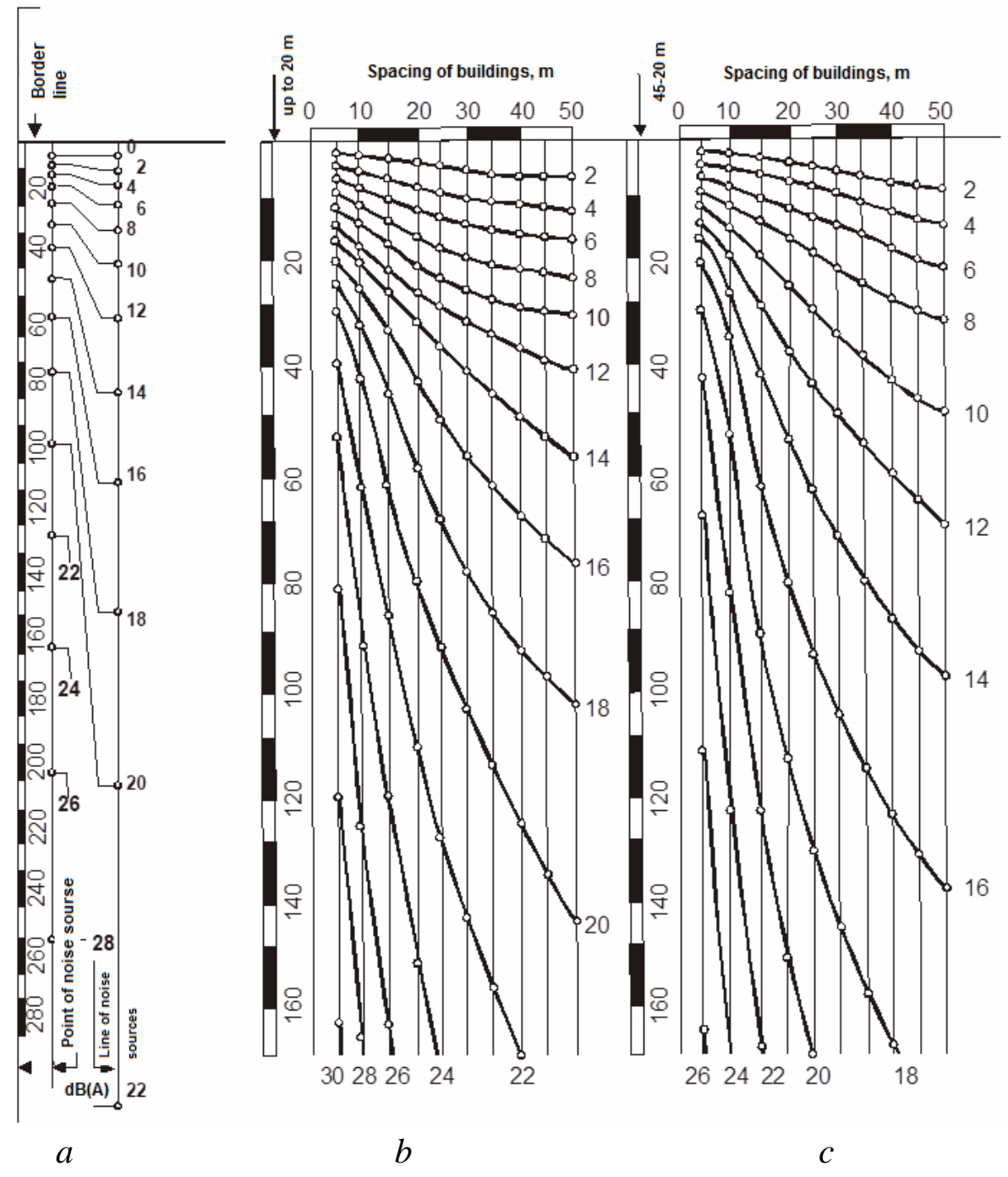

Fig.1 (the beginning). Noise recorder data. The nomographic chart for determining the decrease of noise levels in unbuilt areas and in spacing's of buildings located at the specified distance from the border line [27] 


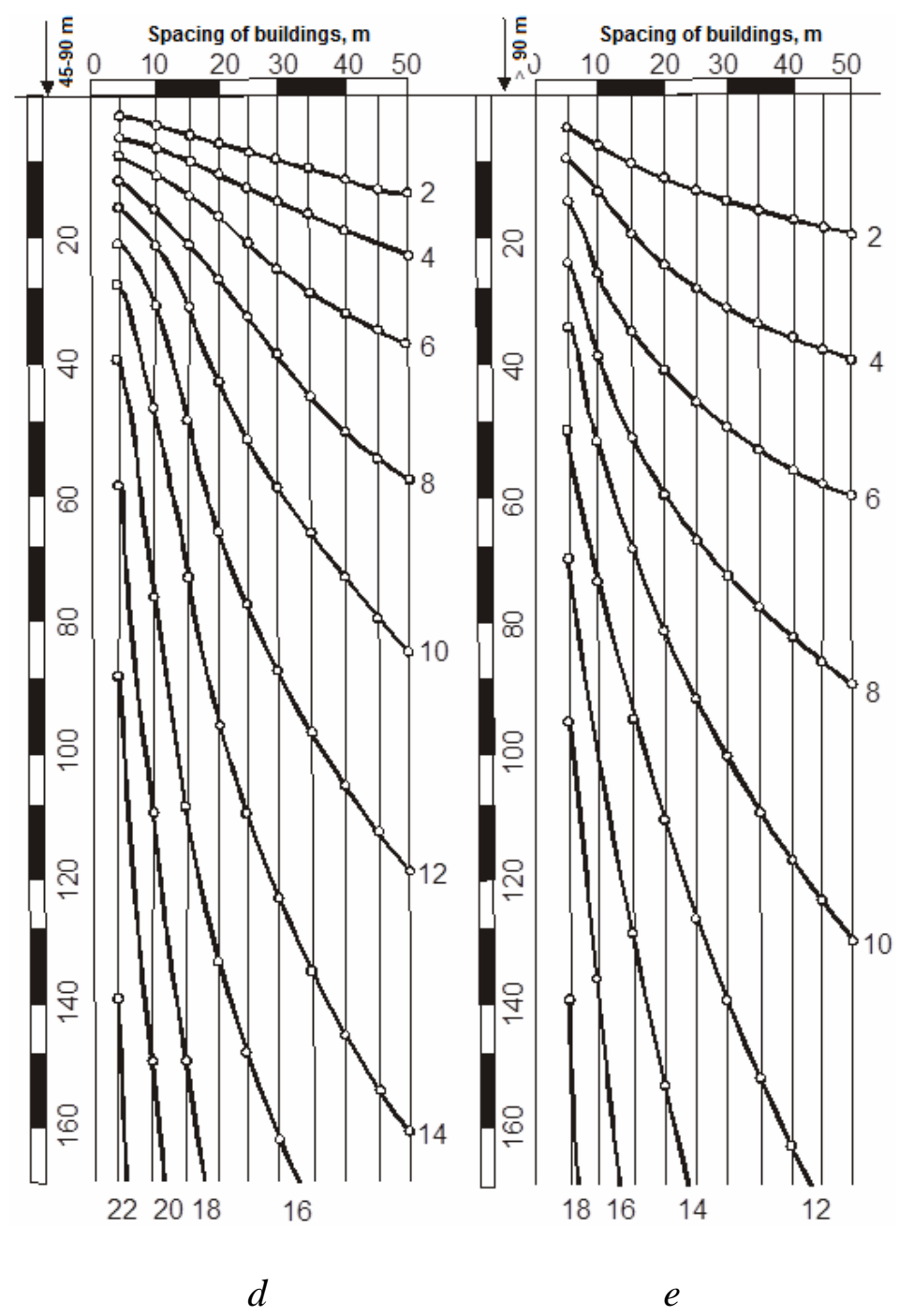

Fig.1 (the end). Noise recorder data. The monographic chart for determining the decrease of noise levels in unbuilt areas and in spacings of buildings located at the specified distance from the border line [27]

For the possibility to use a noise recorder, we determined, on the basis of the experience achieved in designing and analyzing various building projects, the following average spacing of buildings for various building types:

- for industrial buildings, such as production plant buildings, industrial facilities, warehouses, and garages: $10 \mathrm{~m}$;

- for low-rise and mixed buildings: $15 \mathrm{~m}$;

- for high-rise buildings: $20 \mathrm{~m}$.

When performing overall calculations, it is assumed that roadside planted land in areas with individual and single-floor buildings decreases noise levels by $5 \mathrm{~dB}(\mathrm{~A})$.
Limiting acoustic discomfort characteristics should be plotted as follows:

- within unbuilt areas, noise propagation should be determined according to the characteristic describing the propagation of noise from a line noise pollution source [26], or according to the first part of the noise recorder data [27] (Fig.1 a), obtained for the unbuilt area in which decrease of noise levels is caused only by distance from a noise pollution source;

- in areas with smallholding building, parks, or gardens, where the decrease of noise levels is caused by planted land, the width of noise propagation paths should be de- 
termined in the same manner as for unbuilt areas but with consideration for the noise attenuation by $5 \mathrm{~dB}(\mathrm{~A})$ due to the presence of the planted land;

- in areas with buildings of different types, the width of noise propagation paths should be determined according to the spacing's of buildings (Fig. $1 b, c, d, e$ ) with consideration for the characteristic features of the buildings and the characteristics of traffic arteries.

By using a noise recorder, for the specified spacing's of buildings and widths of traffic arteries within the controlled building-up areas, it is required to determine the distance at which the calculated level of noise caused by the presence of the traffic artery decreases to the sanitary standard level.
When determining the width of the noise pollution path from a railway, it is assumed that the basic normative requirements are fulfilled for providing sanitary protection area $100 \mathrm{~m}$ in width and 50-percent planting of the area. In this case, it should be considered that the decrease of noise levels by plants in the sanitary protection area is $6 \mathrm{~dB}(\mathrm{~A})$ on an average. If the traffic artery is located within the railway right of way, the noise levels caused by both the noise pollution sources should be added with consideration for the noise energy generated by each source.

As an example, the use of the proposed method is illustrated by the data in Table 1 , obtained in calculating the traffic noise levels from the main roads in Solomianskyi District in Kyiv.

Table 1 (the beginning). Propagation of noise from main roads in the Solomianskyi District in Kyiv

\begin{tabular}{|c|c|c|c|c|}
\hline & \multirow[b]{2}{*}{ Main roads } & \multicolumn{3}{|c|}{ Existing state } \\
\hline & & $\begin{array}{c}\text { Noise } \\
\text { level, } \mathrm{dB}(\mathrm{A})\end{array}$ & Distance, $\mathrm{m}$ & $\begin{array}{l}\text { Note concerning the } \\
\text { noise propagation } \\
\text { conditions }\end{array}$ \\
\hline \multirow[t]{2}{*}{1} & 2 & 3 & 4 & 5 \\
\hline & Ringway & & & \\
\hline \multirow[t]{2}{*}{1} & From the railway to Odesa Square & 76,5 & $90 / 120^{*}$ & *Unbuilt area \\
\hline & Astronaut Komarov Avenue & & & \\
\hline 2 & From the railway to V.Havel Avenue & 76,6 & 93 & High-rise buildings \\
\hline \multirow[t]{2}{*}{3} & $\begin{array}{l}\text { From V.Havel Avenue to Industrialna } \\
\text { Street }\end{array}$ & 77,9 & 100 & High-rise buildings \\
\hline & Industrialna Street & & & \\
\hline 4 & $\begin{array}{l}\text { From Peremohy Avenue to Borshcha- } \\
\text { hivska Street }\end{array}$ & 80,8 & $170 / 100^{*}$ & *Industrial buildings \\
\hline \multirow[t]{2}{*}{5} & $\begin{array}{l}\text { From Borshchahivska Street to Ushynskyi } \\
\text { Street }\end{array}$ & 78,0 & 115 & High-rise buildings \\
\hline & Chokolivskyi Avenue & & & \\
\hline \multirow[t]{2}{*}{6} & $\begin{array}{l}\text { From Ushynskyi Street to Sevastopolska } \\
\text { Square }\end{array}$ & 77,3 & 100 & High-rise buildings \\
\hline & V.Lobanovskyi Avenue & & & \\
\hline 7 & $\begin{array}{l}\text { From Sevastopolska Street to A.Holovko } \\
\text { Street }\end{array}$ & 77,5 & 97 & High-rise buildings \\
\hline \multirow[t]{2}{*}{8} & $\begin{array}{l}\text { From A.Holovko Street to Kirovohradska } \\
\text { Street }\end{array}$ & 80,0 & 120 & Mixed buildings \\
\hline & Peremohy Avenue & & & \\
\hline 9 & From the railway to Dehtiarivska Street & 79,5 & $135 / 70 * / 85 * *$ & $\begin{array}{l}\text { *Park } \\
* * \text { Industrial buildings }\end{array}$ \\
\hline
\end{tabular}


Table 1 (the end)

\begin{tabular}{|c|c|c|c|c|}
\hline 1 & 2 & 3 & 4 & 5 \\
\hline 10 & $\begin{array}{l}\text { From Dehtiarivska Street to O.Dovzhenko } \\
\text { Street }\end{array}$ & 78,0 & $115 / 55^{*}$ & *Industrial buildings \\
\hline 11 & $\begin{array}{l}\text { From O.Dovzhenko Street to } \\
\text { V.Vasylevska Street }\end{array}$ & 78,3 & $125 / 70^{*}$ & *Industrial buildings \\
\hline \multirow[t]{2}{*}{12} & Borshchahivska Street & 78,0 & 110 & High-rise buildings \\
\hline & Povitroflotskyi Avenue & & & \\
\hline 13 & From the ringway to Volynska Street & 74,9 & 90 & Unbuilt area \\
\hline 14 & $\begin{array}{l}\text { From Volynska Street to Sevastopolska } \\
\text { Square }\end{array}$ & 75,1 & $73 / 30 * / 95 * *$ & $\begin{array}{l}\text { *Park } \\
\text { **Industrial building }\end{array}$ \\
\hline 15 & $\begin{array}{l}\text { From Sevastopolska Square to Solomian- } \\
\text { ska Square }\end{array}$ & 76,7 & $93 / 50 *$ & *Park \\
\hline 16 & $\begin{array}{l}\text { From Solomianska Square to I.Ohienko } \\
\text { Street }\end{array}$ & 78,7 & 115 & High-rise buildings \\
\hline 17 & $\begin{array}{l}\text { From I.Ohienko Street to Borshchahivska } \\
\text { Street }\end{array}$ & 75,2 & 95 & Unbuilt area \\
\hline \multirow[t]{2}{*}{18} & Metropolitan V.Lypkivskyi Street & 76,1 & 87 & High-rise buildings \\
\hline & Solomianska Street & & & \\
\hline 19 & $\begin{array}{l}\text { From Protasiv Yar Street to A.Holovko } \\
\text { Street }\end{array}$ & 72,5 & 40 & High-rise buildings \\
\hline 20 & $\begin{array}{l}\text { From A.Holovko Street to Solomianska } \\
\text { Square }\end{array}$ & 72,4 & $40 / 27^{*}$ & *Park \\
\hline \multirow[t]{2}{*}{21} & Kirovohradska Street & 75,1 & $30 / 37^{*}$ & $*$ Cemetery \\
\hline & V.Havel Avenue & & & \\
\hline 22 & $\begin{array}{l}\text { From Vasylenko Street to Komarov Ave- } \\
\text { nue }\end{array}$ & 73,8 & $50 / 25^{*}$ & *Industrial buildings \\
\hline 23 & $\begin{array}{l}\text { From Komarov Avenue to Vidradnyi Av- } \\
\text { enue }\end{array}$ & 73,0 & $45 / 22^{*}$ & *Industrial buildings \\
\hline \multirow[t]{2}{*}{24} & Medova Street & 71,6 & 50 & Unbuilt area \\
\hline & Narodnoho Opolchennia Street & & & \\
\hline 25 & From Sevastopolska Street to Ernst Street & 72,1 & 38 & High-rise buildings \\
\hline 26 & From Ernst Street to Medova Street & 70,2 & $28 / 15^{*}$ & *Industrial buildings \\
\hline 27 & A.Holovko Street & 73,5 & 48 & High-rise buildings \\
\hline \multirow[t]{2}{*}{28} & Protasiv Yar Street & 76,4 & 115 & Unbuilt area \\
\hline & Vidradnyi Avenue & & & \\
\hline 29 & $\begin{array}{l}\text { From Symyrenko Street to V.Havel Ave- } \\
\text { nue }\end{array}$ & 75,8 & $70 / 38^{*}$ & *Industrial buildings \\
\hline 30 & From V.Havel Avenue to Harmatna Street & 74,3 & 35 & Mixed buildings \\
\hline \multirow[t]{2}{*}{31} & M.Hrinchenko Street & 70,6 & 20 & Mixed buildings \\
\hline & Vasylenko Street & & & \\
\hline 32 & $\begin{array}{l}\text { From Peremohy Avenue to V.Havel Ave- } \\
\text { nue }\end{array}$ & 77,8 & $50 / 30 *$ & *Industrial buildings \\
\hline
\end{tabular}


The noise propagation paths caused by automobile and railway transportation vehicles and determined according to the abovementioned method can be shown on the city district development map at the map scale. The data on the noise propagation paths can be used as basic data for differentiating the urban areas, developing more substantiated noise protection facilities, and taking decisions in relation to the planning and development of the urban areas.

\section{CONCLUSIONS}

The calculated data presented in this paper can be used as basic data in determining limit environmental pressures on the urban areas located near main roads, specifying the functionality of the urban areas, and taking the corresponding decisions for providing the quality of the city environment, selecting methods for the technical protection of the urban areas, studying the urban areas in conditions of compact planning, determining the type of building-up along the city main roads, and simulating the ecological state of the city environment.

\section{REFERENCES}

1. State Construction Norm 360-92. City and City Planning. Planning and Development of Urban and Rural Settlements. Kyiv, Derzhbud Ukrainy, 113 (in Ukrainian).

2. General Planning Scheme of Kyiv for the period through to 2020, 2001. Main Principles, 69 (in Ukrainian).

3. Solukha B.V., Fuks H.B., 2003. Urban Ecology. Kyiv, KNUCA, 337 (in Ukrainian).

4. Furmanenko O.S., 1991, City and Country Cleaning and Refuse Disposal. Kyiv, Budivelnyk, 144 (in Ukrainian).

5. Astern M.M., Solukha B.V., Shilova T.O., 2010. Environmental Evaluation of City Main Road Crossings on Different Levels. Kyiv, KNUCA, 108 (in Ukrainian).

6. Ustynova I.I., 2016. Methodological Framework of Sustainable Development of Environmental City Planning Systems. Synopsis of a thesis, Kyiv, KNUCA, 46 (in Ukrainian).
7. Solukha I.B., 2016. Methods of Urban Environmental Evaluation of Traffic Planning Hubs in Trunk Road Networks of Large Cities. Synopsis of a thesis, Kyiv, KNUCA, 22 (in Ukrainian).

8. Igor Solukha, 2015. The influence of longitudinal slope of main road carriage-way on the mass emission from road transport in the atmospheric air, MOTROL, Vol.17, No.8, 4551.

9. Annual Abstract of Statistics of Kyiv city, 2011. State Statistics Service of Ukraine, 467 (in Ukrainian).

10.Annual Abstract of Statistics of Kyiv city, 2015. State Statistics Service of Ukraine, 434 (in Ukrainian).

11.Osytnianko A.P., 2005. Kyiv Development Planning. KNUCA, 385 (in Ukrainian).

12.Priymachenko O.V., 2014. Determining the Planning Measures for Noise Reduction in the Areas Surrounding Main Roads. City and Land-Use Planning: Collection of scientific and technical articles. Kyiv, KNUCA, Issue 51, 469-474 (in Ukrainian).

13.Priymachenko O.V., 2014. Analysis of Models of Noise Propagation in Space. City and Land-Use Planning: Collection of scientific and technical articles. Kyiv, KNUCA, Issue 53, 435-439 (in Ukrainian).

14.Igor Solukha, 2015. Intersectional junctions of the main roads in city SRN System (on the basis of Kyiv SRN system). MOTROL, Vol.17, No.8, 53-59.

15.Ivanov V.N., Storchevus V.K., 1990, Ecology and Automobilization. Kyiv, Budivelnyk, 129 (in Russian).

16.State Construction Norm B.2.3-5-2001. Streets and Roads of Urban and Rural Settlements. Kyiv, 50 (in Ukrainian).

17.State Sanitary Rule 173-96, 1996. State Sanitary Rules of Planning and Development of Settlements. Kyiv, Ministry of Healthcare of Ukraine, 84 (in Ukrainian).

18.Guidelines on Development of the Chapter of Environmental Protection, 1989. Project to Construction Norms and Regulations, 1.02.01-85, 1989. Moscow, TSNII Proekt Gosstroya SSSR, 187 (in Russian).

19.State Construction Norm A.2.2.1-2003, 2003. Composition and Content of the Materials of Evaluation of Environmental Pressures (EEP) in Designing and Building Enterprises, Houses and Constructions. Main Principles of Design. Kyiv, Derzhbud Ukrainy, 19 (in Ukrainian). 
20.State Construction Norm B.1.1-31:2013, 2013. Protection of Territories, Houses and Constructions from Noise. Kyiv, Minrehion Ukrainy, 75 (in Ukrainian).

21.State Standard of Ukraine DSTU-H Б B.1.133:2013, 2013. Directive on Engineering and Design of Noise Protection of Residential Areas. Kyiv, Minrehion Ukrainy, 42 (in Ukrainian).

22.Ustynova I., 2015. Theoretical principles of wave urbanistics. Underwater Technologies, Vol.01, 33-42.

23.Shilova T.O., 2005. Analysis of acoustic conditions in Kyiv. City and Land-Use Planning: Collection of scientific and technical articles. Kyiv, KNUCA, Issue 20, 392-396 (in Ukrainian).

24.Bystriakov I.K., Shilova T.A., 1991. Estimation of paths of transport noise propagation when designing territorial integrated nature preservation systems. Abstracts of the reports of the All-Union Scientific and Technical Conference "Improvement of City Acoustical Environment: Development and Construction Methods". Sevastopol, 22-24 (in Russian).

25.Priymachenko O.V., 2017. Model for effectiveness evaluation of planning measures for protection of areas surrounding main roads from the influence of environmental pressures on the Kyiv main road network. Underwater Technologies, Vol. 05, 67-73.

26.Osypova H.L., 1993. Noise protection in city planning. Designer Handbook. Stroyizdat, 96 (in Russian).

27.Samoiliuk E.P., Denysenko V.I., Pylypenko A.P., 1981. Noise control in population aggregates. Kyiv, Budivelnyk, 144 (in Ukrainian).

\section{Определение границ акустических загрязнений от магистрали на стадии зонинга территории}

\section{Алексей Приймаченко, Татьяна Шилова}

Аннотация. Повышение автомобилизации в городах влечет за собой ряд проблем по организации движения транспорта, что в свою очередь требует расширения транспортных коридоров улично-дорожной сети увеличения пропускной способности, разработки моделей транспортных потоков в условиях сложившейся застройки города. Также в этих условиях увеличивается и экологическая нагрузка на территорию ее техногенный потенциал влияния начинает расти, что приводит к увеличению концентрации экологических нагрузок. Желание увеличения пропускной способности и плотности застройки может привести к экологической дестабилизации определенных городских территорий. На сегодняшний день существует ряд нормативных документов, которые регламентируют условия застройки и планировки городских территорий.

Формирование функционального назначения территории и определены экологических влияний и их границ должно быть четко определено на стадиях разработки генеральных планов и планов детальной застройки территории.

В условиях децентрализации и формирования территориальных общин, самостоятельного определения их финансового развития в определенных отраслях и формирования социальной среды обитания требует многогранного профессионального подхода к разработке стратегии развития территорий и поселений.

На сегодняшний день специалисты в области градостроительства способны учесть всю многофакторность влияния на формирование развития и планирования территории с учетом последующих экологических нагрузок, их границ влияния, что в дальнейшем даст возможность экономии финансов при разработке мероприятий по снижению техногенного влияния на экологию и среду обитания человека и перспектив регионального развития. Поэтому задача исследования экологических нагрузок от магистральной уличной сети является актуальной для города.

Приведены расчетные данные обследованных магистральных улиц с различными планировочными решениями, собраны данные, необходимые для принятия соответствующих планировочных решений.

Ключевые слова: коридоры распространения звука, кривые акустического дискомфорта, изодецибелы. 